\title{
Change of Direction in Understanding the History of Education in Slovakia in the $1940 s^{1}$
}

\section{BLANKa KudLÁČOvá}

\begin{abstract}
The paper is a historical-educational study that aims to survey changes in the conceptual foundations of the field of the history of education in the 1940s, when a change of direction in its understanding, caused mainly by political circumstances, occurred. It was a complicated period with several overlapping ideological levels: the ideas of the interwar democratic Czechoslovakia "retired", the national socialist ideology of the Slovak state was established in the situation of the war, and the Marxist-Leninist ideology, which was fully implemented after the communist coup in 1948, was being gradually shaped.

A change of direction in the history of education and a change in its foundations will be demonstrated via two leading figures in the pedagogy of the period and their historical-educational work. The first one is Juraj Cecetka (1907-1983), the first Slovak professor of pedagogy. In 1940, he published his work Zo slovenskej pedagogiky [From Slovak Pedagogy], which can be considered the first Slovak scientific publication in the field of the modern history of education. The second personality that significantly influenced the character of pedagogy in Slovakia in the 1940s was Ondrej Pavlik (1916-1996). The conceptual foundations of his writings were different in comparison to Čecetka's work and his successful establishment was aided by political engagement. His pedagogical work was predetermined by a dissertation thesis, Vyvin sovietskeho školstva a pedagogiky (1945) [Development of Soviet Education and Pedagogy], and a monograph, Vysoké skoly $v$ Sovietskom zväze (1947) [Universities in the Soviet Union].

Discussing the work of Juraj Čecetka and Ondrej Pavlik, the following can be pointed out: 1. the close connection between personal conviction and political engagement and scientific work; 2. the impact of the ideology of totalitarian regimes on science and education, and 3. a change of direction in the understanding of the history of education under the influence of totalitarian ideologies and the difficulty of evaluating them objectively.
\end{abstract}

Keywords: history of education, national socialist ideology, Marxist-Leninist ideology, Juraj Čečetka, Ondrej Pavlik.

${ }^{1}$ The study originated with the support of a project of the Ministry of Education of the Slovak Republic, VEGA No. 1/ 0038/17 Educational Thinking, the Education System and Education in Slovakia from 1945 to 1989. 


\section{INTRODUCTION}

The history of education became a part of university education in Slovakia in the $1922 / 23$ academic year. It was a part of the teacher training of secondary school teachers at the newly established Faculty of Arts of Comenius University (henceforth CU) in Bratislava. The Pedagogical Seminar ${ }^{2}$ (Pädagogisches Seminar, Ger.) that provided teacher training was established a year later. Because of the lack of a Slovak intelligentsia after the founding of the Czechoslovak Republic (caused by strong Magyarization on the territory of Slovakia in the second half of the $19^{\text {th }}$ century and the beginning of the $20^{\text {th }}$ century), the seminar was led by three Czech professors of pedagogy in the first two decades. ${ }^{3}$ The first one was Otokar Chlup, who also gave lectures in two historical-educational courses: History of educational theories since the period of the Renaissance and History of pedagogy in the $19^{\text {th }}$ century. ${ }^{4}$ The second professor was Josef Hendrich, who influenced the orientation of the seminar the most and led it for the longest period. He lectured on the history of pedagogy and education with regard to Slovak history and in 1937 he published a book, Ako sa kedysi na Sloven- sku studovalo [How We Once Studied in Slovakia]. In the introductory study, he deals with education in Slovakia in general from the $16^{\text {th }}$ century up to 1918 and in the biographies of four selected figures from Slovak history and culture (Ján Seberíni, Samuel Tomášik, Ján Francisci, and Ján Kalinčiak) he deals with education in Slovakia from the end of the $18^{\text {th }}$ century up to the first half of the $19^{\text {th }}$ century. Jan Uher did not lecture on historical-educational subjects in his short time at the Pedagogical Seminar. He lectured in the field of new pedagogical and psychological directions, which he surveyed critically (see his publication Základy americkej výchovy [The Foundations of American Education], 1936). After the departure of the Czech professors, in 1939, Juraj Čečetka, who was the first Slovak professor of pedagogy, became the director of the Pedagogical Seminar.

\section{ČEČETKA'S UNDERSTANDING OF THE History OF EDUCATION AND His Historical-Educational WRITINGS IN THE 1940s}

After taking over the leadership of the Pedagogical Seminar, Juraj Čečetka (1907-

\footnotetext{
${ }^{2}$ Pedagogical Seminars (Pädagogisches Seminar, Ger.) were associated with professorship in pedagogy, in connection with which a seminar may have been or did not have to be established; its aim was practical - the training of secondary school teachers; the concept originated in the second half of the $19^{\text {th }}$ century.

${ }^{3}$ It concerned pedagogues who gained qualifications in the period when the Pedagogical Seminar at Charles University in Prague was led by Professor Otokar Kádner: Prof. Otokar Chlup led the Pedagogical Seminar in Bratislava from 1923 to 1927, Prof. Josef Hendrich from 1928 to 1937, and Prof. Jan Uher in the 1937/38 academic year (he worked at the Faculty of Arts from 1937 to 1939). Following the declaration of the independence of Slovakia, Chlup received a redundancy decree and had to leave Slovakia (Archive of the CU, Faculty of Arts CU, personal file of Prof. Otokar Chlup, personal file of Prof. Josef Hendrich, and personal file of Prof. Jan Uher). ${ }^{4}$ Archive of the CU, List of lectures...
} 
1983) was prepared to take responsibility for the direction of Slovak pedagogy and the conceptual profiling of the school system in Slovakia. His intentions, however, were influenced by the emergence of two consecutive political regimes that did not favour free scientific and educational work.

In 1939, political changes that were a reaction to the Munich Agreement and the approaching Second World War took place in Slovakia. Even before the beginning of the Second World War, the Slovak Republic was declared on $14^{\text {th }}$ March 1939. Slovak education started to adapt to political requirements; pedagogy developed in a national socialist variant that emphasized national, Christian, and patriotic education (Krankus, 2016). Čečetka had to face the ideology of the Slovak state in this new political environment. The period of the Second World War was scientifically very fruitful in his life; he published significant works on pedagogy and was also active in the field of journal publications. ${ }^{5}$

In 1939, he published a work titled Slovenské evanjelické patronátne gymnázium $v$ Turcianskom sv. Martine [The Slovak Evangelical Patronage Grammar School in Turčiansky St. Martin]. Čečetka had worked on its preparation even in the period before the declaration of the Slovak Republic. The content of the publication is narrowly defined; it consists of four chapters and the publication has 93 pages in total. The content is not marked by the ideology of the period. The only proof of the era can be found in the final sentence in the Introduction: "The institute in Turčiansky St. Martin, despite remaining a lower grammar school, does not lag behind the other two grammar schools, either in educational or national importance; it grows and acts according to the traditional motto of the Slovak struggles: For God and for the Nation" (Čečetka, 1939, p. 3).

Juraj Čečetka was the first Slovak pedagogue who was concerned with the history of Slovak pedagogy. In 1940, he published a work titled Zo slovenskej pedagogiky [From Slovak Pedagogy] in which he describes the development of Slovak educational thinking on the basis of a rich study of sources, mainly pedagogical books and journals and textbooks. The work can be considered the beginning of historical-educational research in modern Slovak history. Before him, the Slovak history of education was explored by the already-mentioned J. Hendrich, ${ }^{6}$ who probably influenced Čečetka’s relationship

\footnotetext{
${ }_{5}^{5}$ Čečetka's work can be divided into three areas: 1. the psychological and pedagogical-psychological area, which is associated with his orientation in the 1930s when he worked at the Psychotechnical Institute in Bratislava; 2. the pedagogical area, with a focus on general pedagogical writing and historical-educational writing, associated with his work at the Faculty of Arts of CU in Bratislava in the 1940s and 1950s, which laid the foundations of modern Slovak pedagogy, and 3. the sociological area, which is associated with his work at the Research Institute of Education in Bratislava since he could not work at the Faculty of Arts of CU (cf. Mihálechová, 2007). ${ }^{6}$ In the discussion concerning the character of pedagogy in the Czech lands, Hendrich inclined to philosophically-oriented pedagogy and criticized empirically-oriented pedagogy and Př́hoda's reform, which is certified, for example, by his publication Filosofické proudy v současné pedagogice [Philosophical Directions in Contemporary Pedagogy], 1926.
} 
to the history of education by his work Ako sa kedysi na Slovensku študovalo [How We Once Studied in Slovakia]. In the introduction to the work he states that "a more comprehensive image of Slovak pedagogy does not exist yet. Works by Križko, Maliak, and Škultéty, for instance, deal only with specific periods of education in Slovakia" (Čečetka, 1940, p. 3). Regarding the orientation of the content, Čečetka states that "the work is devoted only to Slovak educational theory; if we also devoted ourselves to educational practice and the school system, the work would be very extensive" (ibid., pp. 114-115). The publication consists of 120 pages and it is divided into an introduction and four chapters; it has rich notes and an index. Čečetka connects the beginnings of Slovak pedagogy with the first preserved pedagogical writings, "namely the writings of Vavrinec Benedikt of Nedožery from the beginning of the seventeenth century" (ibid., p. 8). Čečetka surveys educational thinking from the Josephian era up to the revolutionary period (1848/49), and afterwards he explores the period up to the closing of the Slovak grammar schools (1874) and concludes with an analysis of pedagogical journals published at the beginning of the $20^{\text {th }}$ century. In the conclusion he states that "our pedagogy was on a fine level; there were individuals who came up with assertive and healthy ideas for their times. International contacts, with educational thinking in particular, were maintained mainly by theologians who studied at the
German universities. However, German or other influences were always adopted reasonably (and then their impacts lasted for a long time, for example, that of Niemeyer) and fashionable pedagogical schools were not created here" (ibid., p. 115). His entire work is exclusively scientific in character and contains a valuable amount of information (Kudláčová, 2015, p. 46). However, in the introduction to this work, the formula "For God and for the Nation" (Čečetka, 1940, p. 6), a typical motto in the period of the first Slovak Republic, can be found.

In the first half of the 1940s, Čečetka published a number of historical-educational studies, mainly in the journal Pedagogický sbornik [Pedagogical Proceedings]. Concerning Čečetka's writing from the period of the Slovak state, our research proves that the ideology of the time did not appear in his books. However, this cannot be stated about his articles published in journals and a change also occurred in the orientation of the content of the journal Pedagogicky sbornik [Pedagogical Proceedings], of which he was an editorin-chief. ${ }^{7}$ The question remains how much it was a matter of his personal conviction and how much it concerned acceptance of the ideology of the time in order to be able to publish the journal (Kudláčová \& Valkovičová, 2015; Valkovičová, 2015). From 1943, a diminution in Čečetka's publication output in Pedagogický sbornik [Pedagogical Proceedings] and also a change in the orientation of the content of the

Cf. Kudláčová, 2015, pp. 42-59; Valkovičová, 2015, pp. 60-72; Kudláčová \& Valkovičová, 2015, pp. 38-51. 
journal can be observed. The question arises of whether this was due to his being busy (he was working on a two-volume Pedagogický lexikón [Lexicon of Pedagogy]) or recognition of the political situation with all its consequences. In regard to the origination of the Slovak Republic, many Slovak intellectuals were enthusiastic about the fact that the Slovaks had an independent state for the first time in their history, not being aware in the beginning of the consequences of its submission to Hitler's policy.

In 1947, Čečetka published another book on Slovak pedagogy: Výber zo slovenských pedagógov [Selection of Slovak Pedagogues]. He dealt with the development of individual systems of education in the world and in Europe in a two-volume work, Pedagogika I-II [Pedagogy I-II] (1947 and 1948), in its first part Vyvin systémov [Development of Systems] in particular. He followed the principle from the conclusion of his publication Zo slovenskej pedagogiky [From Slovak Pedagogy] that "first of all, it is necessary to keep in memory all the significant Slovak pedagogical personalities and only then is it possible to write an educational-philosophical work on the development of the Slovak pedagogical ideology with respect to world pedagogy..." (Čečetka, 1940, p. 115). It is a 304-page-long work containing ten chapters. Čečetka demonstrates a broad scope of knowledge from the field of the history of world pedagogy, as evidenced by a number of notes from the Czech, German, and French literature. This twovolume publication makes it obvious that Čečetka understood the history of education as an essential part of pedagogy as such: a part of pedagogy is represented by the historical reflection of education in the diversity of the "... perspectives of individual pedagogical thinkers. At the same time, individual historical periods and diverse social environments have their specific influence, too" (Čečetka, 1947, p. 9). The history of education, according to him, "cannot be understood as a simple history of some private contemplation, philosophizing about education isolated from life, cultural, social, economic, and similar problems... history of simple educational practices, etc. Education is an integral part of life of humankind, regarding either the internal development of individuals or the development of society." (ibid., p. 30). ${ }^{8}$

Čečetka was confronted with two ideologies in his work in the 1940s: the first was with the ideology of the Slovak state, to which he objected insufficiently strongly, according to the representatives of the postwar regime. On this basis, the rights associated with performing the function of a full professor were removed in 1946 and he was not able to lead the Pedagogical Seminar for two years. In this period, the new ideology of Marxism-Leninism was being enforced and established in all the countries of East-

\footnotetext{
${ }^{8} \mathrm{He}$ also dealt with historical-educational writings in the 1950s: Ucitel' ludu Samuel Tesedik (1952), Vavrinca Benediktiho z Nedožier Vnútorná sústava školská a Reč nápravná (1955), Pedagogické dielo Jána Seberíniho (1957), and a textbook Dejiny školstva a pedagogiky na Slovensku do prvej svetovej vojny (together with P. Vajcik, 1956, 1958).
} 
ern Europe. Čečetka - perhaps being aware of the manners of the previous totalitarian regime - resisted firmly, even at the cost of his departure from the Faculty of Arts. In 1957, he was made redundant for the first time (at the age of 52) and was involuntarily moved to the Slovak Pedagogic Library. From 1964 he worked in the Research Institute of Education in Bratislava, which is related to his sociologically-oriented publications in the 1960s. In 1969, in the period of political release (the Prague Spring), he was able to return to the Faculty of Arts, which gave him a certain satisfaction. However, in the period of 'normalization' in 1971, he was made redundant again and retired prematurely. The repeated purges and political pressures affected his health, and he died on $24^{\text {th }}$ June 1983.

According to Wiesenganger (2014, p. 68), it is difficult to categorize Čečetka’s work within pedagogical conceptions: "he defines himself against individual authors and directions." He formed his own views and opinions very carefully and did not finalize them into a synthesis. His caution, however, could have been related to the "overlapping" of several ideologies in the 1940s and the associated political regimes that reached Čečetka at the peak of his professional life.

\section{PaVlík's Understanding of}

History of Education aNd

a Change of Direction

\section{Toward Soviet Pedagogy}

The second personality who significantly influenced the development of Slo- vak and Czechoslovak pedagogy in the $20^{\text {th }}$ century was Ondrej Pavlík (1916-1996). Pavlík formed his profile through a publication on the history of Soviet pedagogy and education; considering the era - the period of the Second World War and the first Slovak Republic - it was rather intriguing. The conceptual foundations and the way he reached important competencies in the field of pedagogy and education were, in comparison to Čečetka, completely different. His successful political and professional establishment was aided by his activities in the then illegal Communist Party during the Second World War.

Pavlík came from a poor family, which, perhaps, marked his orientation to the left. He graduated from a teachers' institute in Lučenec, he was a teacher at local schools in several villages, and he later graduated in philosophy and biology from the Faculty of Natural Sciences and the Faculty of Arts of CU in Bratislava. As early as in 1939, he joined the then illegal Communist Party and was engaged in the resistance movement (Černák, 2016). His further orientation was indicated by his dissertation thesis, entitled Vývin sovietskeho školstva a pedagogiky [Development of Soviet Education and Pedagogy], which he started writing in 1940 and finished in 1942. However, it could not be published at that time, since Slovakia was at war with the Soviet Union. The thesis was only published after the end of the war in 1945 as a result of the initiative of a literary scientist, Mikuláš Bakoš (Londáková, 2016). The title was modified to Vyvin sovietskeho školstva a pedagogiky so zretelom na školu 
povinnú [Development of Soviet Education with Regard to Compulsory Education] and it was published by the Slovak Academy of Sciences and Arts. A monograph titled Vysoké školy v Sovietskom zväze [Universities in the Soviet Union] (1947) was Pavlík's second publication. Both are considered the first Slovak works on Marxist pedagogy and became a source of theory of the first post-war Czechoslovak reform of education (ibid., 2016). Pavlík can be considered a promoter of Marxist pedagogy in Slovakia. However, it has to be noted that despite Soviet pedagogy and schools being his model, he did not approach them uncritically.

As far as the work Vývin sovietskeho školstva a pedagogiky so zretelom na školu povinnú [Development of Soviet Education with Regard to Compulsory Education] is concerned, it was also Pavlík's habilitation work. Its reviewers were Juraj Čečetka and Josef Hendrich. They were two important pedagogues at that time, and their pedagogical vision stood at completely different starting points from Pavlík's. Čečetka’s review has not yet been obtained for the purposes of our research. Considering Hendrich's review, ${ }^{9}$ on the one hand, a certain disapproval of such an orientation of pedagogy can be assumed, but on the other hand, either generosity or anticipation of a change in the political orientation can be deduced. ${ }^{10}$ Hendrich states that "with regard to the ideological aspect, Pavlík's position is clear. He is a Marxist and the entire subject is presented and criticized from the perspective of implementing the ideals of Marxism in education. However, he is certainly not an uncritical follower" (Hendrich's review, p. 2). In the second chapter, Pavlík deals with the development of tsarist education in the $19^{\text {th }}$ century; in the third chapter, he discusses Marxism. Pavlík sees the contribution of Marxism in the idea of polytechnic education, a survey of which represents a unifying axis of the entire publication. In his opinion, the era has gone too far in limiting polytechnic education, as exemplified, for example, by the cancellation of handicrafts as an independent subject; he criticizes the Soviet pedagogues, for example, Gruzdev, for this (Pavlík, 1945, p. 188 and further). $\mathrm{He}$ takes his criticism even further and criticizes Lenin: "Obviously, Lenin understood polytechnic education rather narrowly and vaguely... He interchanged polytechnic education with general intellectual education..." (ibid., p. 194). In connection to

\footnotetext{
${ }^{9}$ Czech Academy of Sciences, Central Archive, Fond Josef Hendrich.

${ }^{10}$ After leaving Bratislava, Hendrich was appointed a professor at the Faculty of Arts of Charles University in Prague on $1^{\text {st }}$ March 1937. However, following the closing of the Czech universities in October 1939, his activity was stopped for six years. During the first months after the liberation, Hendrich was reactivated, started to lead the Pedagogical Seminar again, and resumed his lecturing activity. He was actively involved in the reform activity aimed at establishing pedagogy as a scientific field at the Faculty of Arts. His reform efforts, however, were not in accordance with the prepared reform of teacher training (the establishment of faculties of education) or with the preparation of the Act on Unified Schools. The Communist coup overtook him at the age of 60 and, exhausted by his struggles to preserve pedagogy at the Faculty of Arts and by the political changes, he died on $5^{\text {th }}$ October 1950 (for more see Váňová, 2005).
} 
Hessen, Pavlík claims that in his case it is "idealistic chatter" (ibid., p. 116). A lot can be understood from Hendrich's conclusion in the review: "Even though he (Pavlík, author's note) proceeds from a viewpoint given in advance, he does not abandon independence and sovereignty. He appears to be a new, original, and qualified individual in our pedagogy. Pavlík's book belongs among the most significant works on our pedagogy since the time of the war, if not the most significant of all" (ibid., p. 5). Since Pavlík wrote the work during the Second World War, as mentioned earlier, it must have been very demanding to obtain the Soviet literary sources. As Hendrich states, "with regard to the Russian conditions under which individual opposition against the official standpoint is not applicable, the choice of characteristic literature is sufficient in order to capture the main features" (ibid., p. 2).

After the end of the war Pavlík found himself at the centre of high politics (after the Slovak National Uprising in 1944 he was already Secretary of the Central Committee of the Communist Party of Slovakia; in 1945 he was a deputy commissioner of the Slovak National Council for education and edification and a member of parliament). He was considered the greatest expert on pedagogy and education in the Communist Party of Slovakia.

In 1948, he was appointed a full professor at the Faculty of Education of CU in Bratislava and he started to lecture on pedagogy based on Marxism-Leninism (at that time he was only 32 years old, which demonstrates his ambition). Pavlík also led the committee for the elaboration of a national Act on Education; the committee was established in 1946 in Prague. They produced two proposals for the reform of education (a Slovak proposal by Pavlík and a Czech proposal by Prríhoda). Eventually, Pavlík's proposal was adopted and it represented a basis for the new Act on Education after the communist coup in 1948. It introduced free education for all. but, at the same time, the establishment of a state monopoly on education with a pro-Soviet orientation (Londáková, 2007). Science and education were thus cut off from the development of science and education in Western Europe and the world until 1989.

Even though Pavlík did not profile as a historian of education later on, his works laid the foundation of pedagogy based on the ideology of Marxism-Leninism, which was gradually established in all its disciplines, including the history of education.

\section{DisCUSSION AND Conclusion}

The 1940s in Slovakia represent a turning point in the development of pedagogy, as well as the history of education, which started to shape at the scientific level mainly thanks to Juraj Čečetka, a student and follower of several important Czech pedagogues and psychologists at Charles University in Prague. He was also influenced by Professor Hendrich, who directed him toward the field of pedagogy during the time he led the Pedagogical Seminar at the Faculty of Arts of CU in Bratislava. Čečetka was an example of a scientist and 
academic who managed to assert himself through his own work and diligence. His first publications were a demonstration of conscientious scientific work in the period of the progressive development of pedagogy under the democratic conditions of the first Czechoslovak Republic. Unfortunately, his life was subsequently affected by two political regimes that influenced his professional life, too. Čečetka, perhaps in a fit of enthusiasm caused by what was historically the first Slovak state, succumbed to the ideology of national socialism for a certain period of time, which can be noticed mainly in his journal publications. From 1943, a reversal in his orientation toward German pedagogy and education can be observed (Kudláčová, 2015; Kudláčová \& Valkovičová, 2015). The question remains whether this was caused by his experiences and the things he encountered during the period of the Slovak state or by a prediction of the end of the Second World War and its winner. One of the hypotheses is that his submission to the ideology of the time was caused by the possibility of developing pedagogy and education in the conditions of the first Slovak state and he needed some time to orientate himself in the prevailing political situation. Čečetka was not a member of Hlinka's Slovak People's Party, which could be one of the proofs of this hypothesis. He resisted the doctrine of socialism and he was not a member of the Communist Party of Czechoslovakia, which caused his persecution. ${ }^{11}$

Ondrej Pavlík, on the contrary, was definitely more a politician than a scientist. This was his inclination from his youth onwards; perhaps, he had a strong intuition that helped him orientate himself in the prevailing political situation. After 1945 , under his influence, educational science, including the history of education, too, started to turn toward Soviet pedagogy. ${ }^{12}$ Štverák (1983) writes that after 1945 a new approach to the treatment of the history of education in the works of Marxist historians of education appeared. ${ }^{13}$ Historical materialism became the methodological basis for the history of education.

\footnotetext{
${ }^{11}$ Čečetka's professional life and work have been discussed in one outline monograph so far, written by Mária Mihálechová (Život a dielo Juraja Čečetku, 2007). Reflection on his work is being researched by the author of the present paper (some of her studies were mentioned in footnote No. 7) and Marek Wiesenganger (e.g. Wiesenganger, 2014, pp. 60-69; Kudláčová, 2015, pp. 73-82 and pp. 117-137).

${ }_{12}$ Pavlík's professional life and work have not been revalued yet. The Museum of Education and Pedagogy in Bratislava organized a commemorative meeting on the occasion of the 100th anniversary of his birth; a collection of papers was published under the editorship of Michalička and Slezáková, entitled Ondrej Pavlik (1916-1996), 2016. Ondrej Pavlík wrote approximately two thousand pages of a memoir that was donated to the National Archive in Bratislava by his wife; however, after the intervention of his son, the memoir was withdrawn.

${ }^{13}$ The fact that the history of education based on the historical materialism of the Soviet authors influenced several generations of teachers and pedagogues in Slovakia is certified by the following translations: Dejiny pedagogiky by J. N. Medynskij (translated by J. Mihál, published in 1950, in Czech translation in 1953) and Déjiny pedagogiky by N. A. Konstantinov, J. N. Medynskij, \& M. F. Šabajeva (translated by J. Váňa, published in 1959).
} 
The majority of the Slovak historians of education identified with this approach in order to be allowed to publish and work at universities. The continuity of the histori- cal-educational research initiated by Juraj Čečetka was interrupted and thus, the history of education was placed outside the scientific framework until 1989.

\section{References}

Černák, T. (2016). Ondrej Pavlík - lavicový intelektuál v odboji a v Povstaní. In V. Michalička \& M. Slezáková (Eds.), Ondrej Pavlik (1916-1996) (pp. 13-22). Bratislava: CVTI SR. Čečetka, J. (1939). Slovenské evanjelické patronátne gymnázium v Turčianskom sv. Martine. Turčiansky sv. Martin: Kníhtlačiarsky účastinársky spolok.

Čečetka, J. (1940). Zo slovenskej pedagogiky. Turčiansky sv. Martin: Matica slovenská.

Čečetka, J. (1947). Pedagogika. Vývin systémov, I. čast. Liptovský sv. Mikuláš: Tranoscius.

Hendrich, J. (1937). Ako sa kedysi na Slovensku študovalo. Turčiansky sv. Martin: Matica slovenská.

Krankus, M. (2016). Recepcia svetového pedagogického myslenia v slovenskej pedagogike. In B. Kudláčová (Ed.), Pedagogické myslenie, školstvo a vzdelávanie na Slovensku v rokoch 1918-1945 (pp. 86-116). Trnava: Typi Universitatis Tyrnaviensis.

Kudláčová, B. (2015). Charakteristika vybraných reprezentatívnych diel slovenskej pedagogiky v rokoch 1939-1945 z hl'adiska spoločensko-politického kontextu. In B. Kudláčová (Ed.), Pedagogické myslenie a školstvo na Slovensku v rokoch 1939-1945 (pp. 42-59). Trnava: Typi Universitatis Tyrnaviensis.

Kudláčová, B., \& Valkovičová, L. (2015). Tvorba Juraja Čečetku a ideológia Slovenského štátu v rokoch 1939-1945. Historia Scholastica, 1(2), 38-51.

Londáková, E. (2007). Modernizácia výchovy a vzdelávania na Slovensku v 2. polovici 20. storočia. Bratislava: VEDA.

Londáková, E. (2016). Ondrej Pavlík a prvá komunistická školská reforma v jej československých politicko-historických konotáciách. In V. Michalička \& M. Slezáková (Eds.), Ondrej Pavlik (1916-1996) (pp. 23-31). Bratislava: CVTI SR.

Mihálechová, M. (2007). Život a dielo Juraja Čečetku. Bratislava: Infopress.

Pavlík, O. (1945). Vývin sovietskeho školstva a pedagogiky so zretelom na školu povinnú. Bratislava: Slovenská akadémia vied a umení.

Štverák, V. (1983). Stručné dejiny pedagogiky. Praha: SPN.

Valkovičová, L. (2015). Štúdie Juraja Čečetku v časopise Pedagogický sborník v období druhej svetovej vojny. In B. Kudláčová (Ed.), Pedagogické myslenie a školstvo na Slovensku $v$ rokoch 1939-1945 (pp. 60-72). Trnava: Typi Universitatis Tyrnaviensis.

Váňová, R. (2005). Pražská léta Josefa Hendricha (1936-1950). In Š. Švec \& M. Potočárová (Eds.), Rozvoj študijného a vedného odboru pedagogika na Slovensku (pp. 77-82). Bratislava: UK. 
Wiesenganger, M. (2014). Filozoficko-výchovné východiská J. Čečetku v diele Úvod do všeobecnej pedagogiky. In B. Kudláčová (Ed.), Pedagogické myslenie a školstvo na Slovensku $v$ medzivojnovom obdobi (pp. 60-69). Trnava: Typi Universitas Tyrnaviensis.

Archival Sources

Archive of the CU, Faculty of Arts CU, Rectorate Coll., Personnel Department, reg. mark. B II/2, personal file of prof. Otokar Chlup, box No. 73.

Archive of the CU, Faculty of Arts CU, Rectorate Coll., Personnel Department, reg. mark. B II/2, personal file of prof. Josef Hendrich, box No. 60.

Archive of the CU, Faculty of Arts CU, Rectorate Coll., Personnel Department, reg. mark. B II/2, personal file of prof. Jan Uher, letter No. 130.823/38-IV.

Archive of the CU, List of lectures at CU in Bratislava in the 1923/24 to 1925/26 academic years, AS CU, Bratislava.

Czech Academy of Sciences, Central Archive, Fond Josef Hendrich, Box No. 3, reg. mark. 115. O. Pavlík`s book "Vývin školstva" [Development of Education] review, 5 pp., typescript.

Prof. PhDr. Ing. Blanka Kudläcová, PhD.

Trnava University in Trnava, Faculty of Education, Department of Educational Studies;

e-mail: blanka.kudlacova@truni.sk 